\title{
Listrik Tenaga Surya untuk Pompa Submersible pada Greenhouse Hidroganik di Kabupaten Malang
}

\author{
Hery Budiyanto1, Pindo Tutuko', Aries Boedi Setiawan², Razqyan Mas Bimatyugra Jati', \\ Muhammad Iqbal ${ }^{3}$ \\ 'Departemen Arsitektur, Fakultas Teknik, 2Departemen Teknik Elektro, Fakultas Teknik, ${ }^{3}$ Departemen Magister \\ Arsitektur Program Pascasarjana \\ Universitas Merdeka Malang, Jl. Terusan Raya Dieng 62-64 Malang, Indonesia
}

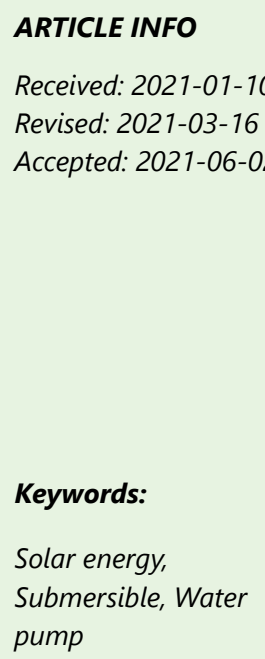

\section{ARTICLE INFO}

\section{ABSTRACT}

This service activity is the application of an innovative submersible solar pump in a hydro-organic greenhouse environment in Grangsil Jambangan, Malang Regency. This is motivated by the need for water that can only be obtained through deep wells with submersible pumps in hydro-organic greenhouses that already use solar power plants but have insufficient power. The purpose of this service is to provide theoretical and practical understanding for Tour conscious group (POKDARWIS) Jambangan members as managers of the hydro-organic greenhouse. The methods used include focus group discussions (FGD) and joint practice in developing solar power plants for submersible pumps. After the implementation of this program, there was an increase in the capacity of the solar power plants, which has been able to turn on submersible pumps, hydroganic circulation pumps and other needs. In one day, the submersible pump only needs to be turned on for 2 hours and produces 4,572 liters of water, sufficient for greenhouse hydroganic needs and other needs. Another positive impact is that POKDARWIS Jambangan members have been able to manage and maintain PLTS for a hydro-organic greenhouse. The submersible water pump prototype for hydroganic agriculture at the greenhouse using independent energy is very practical and efficient so it is expected to become a prototype for modern agricultural facilities in the context of a national scale food security improvement program.

(C)2021 Published by University of Merdeka Malang. This is an open access article distributed under the CC BY-SA 4.0 license (https://creativecommons.org/licenses/by-sa/4.0/)

How to cite: Budiyanto, H., Tutuko, P., Setiawan, A. B., Jati, R. M. B., \& Iqbal, M. (2021 Listrik Tenaga Surya untuk Pompa Submersible pada Greenhouse Hidroganik di Kabupaten Malang. Abdimas: Jurnal Pengabdian Masyarakat Universitas Merdeka Malang, 6(3), 336-346. https://doi.org/10.26905/abdimas.v6i3.5298

\section{PENDAHULUAN}

Kegiatan pengabdian ini berangkat dari adanya masalah sumber air yang merupakan salah satu kebutuhan dasar bagi pertanian sayur pada kawasan greenhouse dengan metode hidroganik di Kampung Grangsil, Desa Jambangan, Kecamatan Dampit, Kabupaten Malang (Budiyanto et al., 2019) yang dikelola oleh mitra pengabdian, yaitu Kelompok Sadar Wisata (POKDARWIS) Desa Jambangan. Meskipun saat 
ini sumber air bersih sudah tersedia yaitu sumber air bersih yang dikelola Desa Jambangan untuk disalurkan melalui pipa-pipa ke kawasan Dusun Grangsil, namun pada musim kemarau penggunaan air bersih mengalami peningkatan dan penyediaan air bersih diutamakan untuk kebutuhan rumah tangga, sehingga kawasan pertanian kebun dan tegalan termasuk kawasan greenhouse hidroganik Grangsil tidak mendapatkan pasokan air. Upaya yang dilakukan adalah mengebor tanah untuk membuat sumur dalam dan menaikkan air menggunakan pompa submersible dengan sumber listrik genset. Meskipun sistem ini dapat menyediakan air jika diperlukan, namun ada beberapa kelemahan signifikan penggunaan listrik genset (Rif'an et al., 2012), antara lain: (1) Bahan bakar harus diangkut ke lokasi genset yang cukup jauh dari jalan dan lanskap curam; (2) Suara bising dan asapnya genset dapat mengganggu; (3) Biaya bahan bakar mahal, dan tumpahan dapat mencemari tanah. Untuk itu diperlukan solusi, salah satunya adalah menggunakan teknologi Pembangkit Listrik Tenaga Surya (PLTS) untuk menggerakkan pompa air submersible, hal ini sesuai dengan konsep green-energy (Kalyani et al., 2015) yaitu penggunaan sumber energi alternatif untuk menghasilkan listrik, di samping itu kondisi geografis Indonesia pada umumnya selalu mendapatkan cahaya matahari sehingga sangat layak menggunakan sinar matahari sebagai sumber energi listrik (Muttaqin et al., 2016). Pemanfaatan photovoltaic (PV) pada saat ini sebagai sumber energi listrik untuk pompa air di masyarakat masih tergolong sebagai teknologi baru. Hartono \& Purwanto (2015) serta Sontake \& Kalamkar (2016) menyatakan bahwa penggunaan teknologi PV sebagai penyedia listrik untuk Sistem Pompa Air Tenaga Surya (SPATS) dapat meminimalkan ketergantungan pada listrik berbasis diesel, gas, dan batubara serta dapat memberikan keuntungan dari segi lingkungan untuk mengoperasikan pompa air konvensional. Pemilihan pompa air submersible adalah berdasarkan efisiensi pompa ini dibanding pompa jenis lain, misalnya jet pump, karena keseluruhan komponen dari pompa submersible selalu terendam dalam air yang akan dipompakannya (Sofyar, 2017). Untuk mendapat laju aliran / debit yang baik maka performa pompa submersible sangat dipengaruhi oleh sumber energinya, karena itu jumlah energi listrik yang diperlukan harus disesuaikan untuk menunjang kapasitas pompa submersible yang digunakan (Setiawan et al., 2017). Pada kasus pompa submersible di Grangsil, setelah dilakukan pencarian sumber air dalam dan dilakukan pengeboran, maka sumber air yang kontinyu baru didapat pada kedalaman 60 meter, sehingga memerlukan pompa submersible. Untuk mengangkat air dari kedalaman 60 meter diperlukan pompa submersible dengan daya minimal 450 Watt.

Program Pengabdian ini dimulai dengan diskusi kelompok terarah (FGD) Tim Pengabdian dengan Mitra yaitu POKDARWIS Desa Jambangan untuk melakukan evaluasi kinerja PLTS yang ada di kawasan greenhouse hidroganik Grangsil terhadap rencana pemasangan sumur dalam submersible. Kemudian dilakukan re-design sistem PLTS pada lingkungan greenhouse hidroganik, hasilnya dilakukan FGD lagi untuk menunjukkan design baru PLTS lingkungan greenhouse hidroganik. Tahap berkutnya dilakukan perhitungan kecukupan daya PLTS untuk bisa mengaliri listrik pompa submersible, pompa sirkulasi air hidroganik, dan lampu penerangan di lingkungan greenhouse hidroganik. Tahap selanjutnya adalah kegiatan bersama tim pengabdian dan mitra dalam pemasangan instalasi PLTS berupa: panel surya fotovoltaik, controller, battery, dan inverter. Panel surya dapat merubah cahaya matahari menjadi menjadi arus listrik searah (DC). Konversi energi radiasi menjadi energi listrik yang memanfaatkan efek fotovoltaik saat ini baru mencapai 25\%, sehingga hasil maksimal hanya 250 Watt per m2 (Suryani et al., 2018). Panel surya yang digunakan pada program ini adalah jenis polycrystallin yaitu panel surya yang tetap bisa 
ABDIMAS: Jurnal Pengabdian Masyarakat Universitas Merdeka Malang Volume 6, No. 3, August 2021: 336-346

menyerap energi sinar matahari meskipun cuaca mendung dibandingkan jenis monocrystallin (Pratama \& Siregar, 2018). Listrik yang dihasilkan PLTS akan menggerakkan pompa submersible sumur dalam untuk mengangkat air melalui pipa saluran air menuju bak penampungan, selanjutnya air disalurkan dari bak menuju greenhouse hidroganik. Langkah berikut adalah pengujian efektivitas penggunaan PLTS untuk penyediaan air pada greenhouse hidroganik, meliputi kekuatan sinar matahari, daya yang dihasilkan PLTS, debit air yang dihasilkan oleh pompa submersible.

\section{METODE}

\section{Diskusi kelompok terarah (FGD)}

FGD berupa pertemuan antara tim pengabdian dengan anggota POKDARWIS, berupa pengenalan anggota tim pelaksana dan penjelasan program serta langkah-langkah masing-masing kegiatan (Indrizal, 2014). Penggunaan FGD sebagai bentuk interaksi atau komunikasi yang dijalin antara tim pengabdian dengan para peserta anggota POKDARWIS. Metode FGD dilakukan di dalam ruangan dan di lapangan (Ekawita et al., 2020) dengan mengajak anggota POKDARWIS bersama dengan tim pengabdian untuk melaksanakan pemasangan PLTS bagi pompa submersible. Sehingga anggota POKDARWIS dapat melihat dan mempraktikan penerapan teknologi tepat guna PLTS secara maksimal.

\section{Praktik}

Metode praktik dilakukan agar mitra yaitu anggota POKDARWIS dapat menerapkan pengetahuan yang didapat dari Diskusi Kelompok Terarah (FGD). Praktik lapangan laksanakan dengan bimbingan kepada peserta untuk aplikasi teknologi PLTS untuk pompa submersible (Santoso et al., 2020).

\section{Re-design}

Re-design merupakan panduan bagi mitra untuk mengetahui PLTS untuk pompa submersible. Isi dari re-design yang digunakan merupakan beberapa hasil design berdasarkan perhitungan daya listrik dan kebutuhan elemen/komponen PLTS untuk pompa submersible (lqtimal et al., 2018).

\section{Evaluasi}

Tolakukur pencapaian kegiatan penerapan inovasi PLTS untuk pompa submersible meliputi 3 kriteria, yaitu: (1) Waktu dan jumlah pertemuan yang sesuai dengan rencana kegiatan; (2) Kemampuan peserta dalam menerapkan teknologi PLTS untuk pompa submersible; (3) Kemampuan pelaksana menjelaskan serta mengkoordinir peserta dalam menerapkan teknologi PLTS untuk pompa submersible.

\section{HASIL DAN PEMBAHASAN}

\section{Hasil}

Pelaksanaan program pengabdian dibagi kedalam dua tahap yaitu: (1) Penjelasan dan praktik pemasangan PLTS untuk pompa submersible yang dibagi menjadi 3 (tiga) aktivitas yaitu pengenalan, 
pelaksanaan, dan penutupan; (2) Evaluasi terhadap rencana dengan realisasi pelaksanaan dan hambatanhambatan yang terjadi selama program pengabdian.

\section{Pelaksanaan}

\section{Diskusi Kelompok Terarah (FGD)}

FGD berupa penjelasan kegiatan pengabdian antara lain: rencana aktivitas serta teknik pelaksanaan di lapangan (Zainuddin et al., 2019). Pada FGD juga diberikan gambaran re-design PLTS. Sehingga peserta mengetahui kondisi awal dan gambaran jadinya setelah dilakukan penyempurnaan PLTS dan penambahan komponen pelengkap lainnya.

\section{Pengenalan komponen PLTS untuk pompa submersible}

Bertujuan agar peserta mengetahui komponen dan teknologi (Sanjaya et al., 2019) PLTS untuk pompa submersible.

\section{Perancangan ulang (re-design) dan perhitungan daya listrik}

Re-design dan perhitungan yang dibuat tim pengabdian dapat dipelajari peserta sehingga memudahkan dalam penerapan di lapangan.

\section{Re-design Pompa Submersible Tenaga Surya}

Pada tahap awal dilakukan pembuatan gambar desain prototipe pompa submersible tenaga surya untuk greenhouse hidroganik, sebagaimana terlihat pada Gambar 1 dan 2.
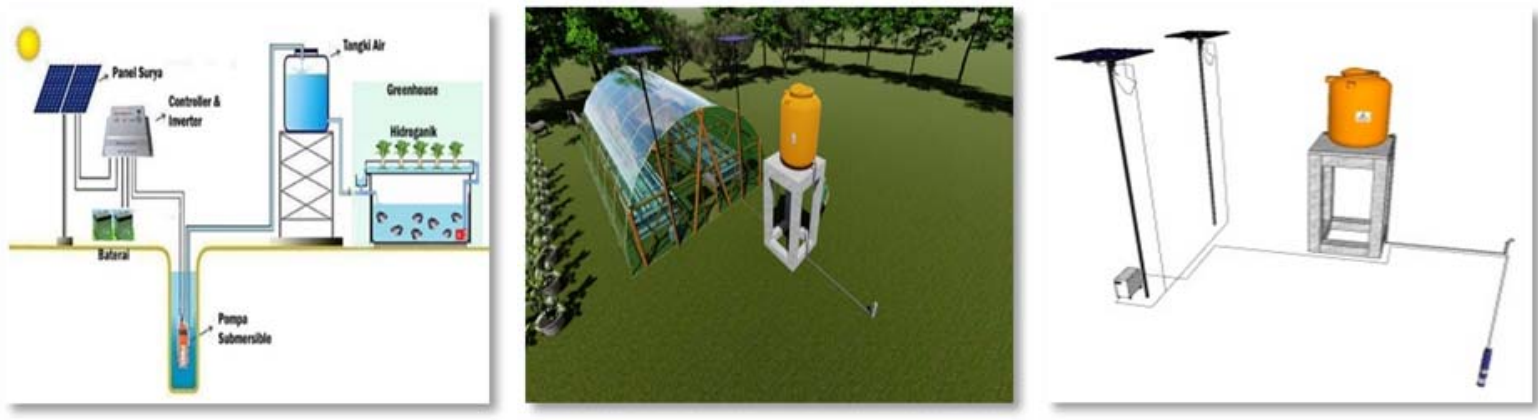

Gambar 1. Skema prototipe pompa submersible tenaga surya untuk greenhouse hidroganik Gambar 2. Desain prototipe pompa submersible tenaga surya untuk greenhouse hidroganik

\section{Perhitungan daya PLTS}

\section{Kebutuhan daya}

Untuk menghitung jumlah watt daya yang dibutuhkan oleh Pembangkit Listrik Tenaga Surya maka perlu dihitung beban selain peralatan pompa air submersible juga pompa sirkulasi air di greenhouse 
ABDIMAS: Jurnal Pengabdian Masyarakat Universitas Merdeka Malang Volume 6, No. 3, August 2021: 336-346

hidroganik yang ditanggung oleh PLTS. Pada sistem PLTS selalu ada daya yang hilang, sehingga demi amannya perhitungan beban total watt jam perhari dikalikan dengan 1,3 (Rosalina \& Sinduningrum, 2019).

Tabel 1. Kebutuhan daya listrik

\begin{tabular}{lccc}
\hline \multicolumn{1}{c}{ Instrumen } & Daya (Watt) & Durasi (H) & Daya WH \\
\hline 1 buah pompa submersible & 450 & 2 & 900 \\
2 buah pompa sirkulasi Hidroganik & 70 & 12 & 840 \\
\hline \multicolumn{1}{c}{ Total kebutuhan daya } & & & 1.740 \\
\hline
\end{tabular}

Catatan: Total kebutuhan tersebut dikalikan 1,3 sehingga 1.740 x 1,3 $=2.262$ watt jam per-hari

\section{Kebutuhan panel surya}

Menurut perhitungan, energi surya yang dapat diserap dan dikonversi menjadi energi listrik di Indonesia berlangsung selama 5 jam (Muttaqin et al., 2016), karena itu untuk menghitung berapa kebutuhan modul surya adalah dengan cara membagi angka kebutuhan daya tersebut dengan 5, maka didapatkan kebutuhan energi listrik sebagai berikut.

$2.262: 5=452,4$ wattpeak

Panel surya yang digunakan pada program pengabdian ini berukuran $250 \mathrm{Wp}$. Kebutuhan panel surya secara perhitungan adalah kebutuhan watt peak dibagi nilai daya panel surya sebagai berikut.

$452,4: 250=1,8 \sim$ dibulatkan ke atas menjadi 2 panel surya

\section{Perhitungan jumlah battery}

Ukuran battery ditentukan berdasarkan tegangan dalam satuan Volt (V) dan daya dalam satuan Ampere Jam (Ah), Menggunakan battery dengan daya $12 \mathrm{~V}$, battery hanya digunakan $50 \%$ untuk pemenuhan kebutuhan listrik (Purwanto, 2020), dengan demikian kebutuhan daya dikalikan 2, yaitu $1.740 \times 2=3.480$ Watt hour, maka kebutuhan battery sebagai berikut.

3.480 / 12 Volt / $100 \mathrm{Amp}=2,9 \sim$ dibutuhkan minimum 3 buah battery 100 Ah $12 \mathrm{~V}$.

Berdasarkan perhitungan tersebut maka komponen/instrumen yang dipakai pada pompa submersible tenaga surya ditunjukkan pada Tabel 2 .

Tabel 2. Instrumen pompa submersible energi surya

\begin{tabular}{ll}
\hline \multicolumn{1}{c}{ Instrumen } & \multicolumn{1}{c}{ Kapasitas } \\
\hline Pompa air submersible & 450 Watt, head 50-60 meter \\
Solar panel & $250 \mathrm{Wp} 24 \mathrm{~V}$ \\
Battery & $100 \mathrm{Ah} 12 \mathrm{~V}$ \\
Inverter & 1.500 Watt \\
Tandon air (atas) & 500 liter \\
Kolam air (bawah) & 5.000 liter \\
\hline
\end{tabular}


Listrik Tenaga Surya untuk Pompa Submersible pada Greenhouse Hidroganik di Kabupaten Malang

Hery Budiyanto, Pindo Tutuko, Aries Boedi Setiawan, Razqyan Mas Bimatyugra Jati, Muhammad lqbal

Berdasarkan perhitungan tersebut maka dilakukan penggantian seluruh instrumen agar mampu memberikan daya listrik yang dibutuhkan untuk pompa submersible energi surya.

\section{Review}

Merupakan tahap akhir berupa penilaian hasil yang telah dilaksanakan oleh kolaborasi tim pengabdian dan anggota POKDARWIS disertai penjelasan oleh tim pengabdian tentang program PLTS untuk pompa submersible beserta kelengkapannya.

\section{Penutupan}

Bentuk kegiatannya berupa sesi perpisahan pihak tim pengabdian dengan anggota POKDARWIS yang dilangsungkan di kawasan greenhouse hidroganik.

\section{Materi kegiatan}

Materi yang digunakan dalam pelaksanaan program pengabdian disesuaikan dari hasil dari penelitian terdahulu (Iqtimal et al., 2018) yang berkaitan dengan pembuatan PLTS untuk menggerakkan pompa submersible serta referensi dari pelaksanaan sejenis yang sudah pernah dilakukan oleh peneliti atau pengabdi sebelumnya (Hartono \& Purwanto, 2015; Apribowo \& Anwar, 2017). Materi dalam kegiatan pengabdian pada masyarakat ini dibagi menjadi 7 (tujuh) kali FGD seperti pada Tabel 3.

Tabel 3. Jadwal pertemuan FGD

\begin{tabular}{|c|c|}
\hline \multicolumn{2}{|l|}{ FGD 1} \\
\hline Aktivitas & $\begin{array}{l}\text { - Penjelasan metode pelaksanaan } \\
\text { - Perkenalan tim pengabdian } \\
\text { - Penjelasan program pengembangan PLTS untuk pompa submersible } \\
\text { - Pengenalan contoh PLTS } \\
\text { - Mengenalkan metode pelaksanaan program } \\
\text { - Pengenalan alat PLTS }\end{array}$ \\
\hline \multicolumn{2}{|l|}{ FGD 2} \\
\hline $\begin{array}{l}\text { Aktivitas } \\
\text { Tujuan }\end{array}$ & $\begin{array}{l}\text { - Pengenalan re-design PLTS untuk pompa submersible } \\
\text { - Penjelasan perhitungan daya dan kapasitas komponen PLTS } \\
\text { - Desain dan perhitungan untuk menghasilkan PLTS pompa submersible }\end{array}$ \\
\hline \multicolumn{2}{|r|}{ 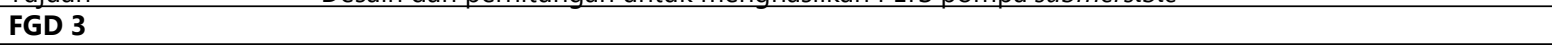 } \\
\hline $\begin{array}{l}\text { Aktivitas } \\
\text { Tujuan }\end{array}$ & $\begin{array}{l}\text { - Penjelasan komponen PLTS untuk pompa submersible dan fungsi masing-masing } \\
\text { - Untuk memberikan pengetahuan tentang komponen-komponen PLTS untuk pompa submersible }\end{array}$ \\
\hline \multicolumn{2}{|r|}{ - } \\
\hline $\begin{array}{l}\text { Aktivitas } \\
\text { Tujuan }\end{array}$ & $\begin{array}{l}\text { - Pemasangan seluruh komponen PLTS dan pompa submersible } \\
\text { - Peserta dapat memahami cara pemasangan seluruh komponen PLTS dan pompa submersible }\end{array}$ \\
\hline \multicolumn{2}{|r|}{ 9 } \\
\hline $\begin{array}{l}\text { Aktivitas } \\
\text { Tujuan }\end{array}$ & $\begin{array}{l}\text { - Pengujian kuat cahaya matahari, daya panel surya, dan kinerja pompa submersible } \\
\text { - Memberikan pengetahuan kepada peserta bahwa dengan PLTS yang sudah terpasang mampu un- } \\
\text { tuk beroperasi menghasilkan daya listrik untuk pompa submersible, pompa sirkulasi hidroganik, dan } \\
\text { lampu di lingkungan greenhouse hidroganik }\end{array}$ \\
\hline \multicolumn{2}{|r|}{ 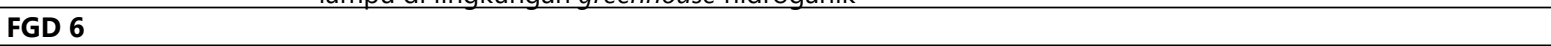 } \\
\hline $\begin{array}{l}\text { Aktivitas } \\
\text { Tujuan }\end{array}$ & $\begin{array}{l}\text { - Evaluasi terhadap kinerja seluruh komponen PLTS dan pompa submersible serta pompa sirkulasi air } \\
\text { greenhouse } \\
\text { - Memberikan penilaian terhadap kinerja alat }\end{array}$ \\
\hline \multicolumn{2}{|r|}{ ( } \\
\hline Aktivitas & $\begin{array}{l}\text { - Kata penutup dan ucapan terima kasih kepada anggota POKDARWIS } \\
\text { - Review hasil kegiatan } \\
\text { - Sebagai salam perpisahan dan ucapan terima kasih kepada peserta dan pihak mitra pengabdian dan } \\
\text { menunjukkan hasil dari pelaksanaan program } \\
\text { - Review hasil PLTS untuk pompa submersible }\end{array}$ \\
\hline
\end{tabular}


ABDIMAS: Jurnal Pengabdian Masyarakat Universitas Merdeka Malang Volume 6, No. 3, August 2021: 336-346

Hari pertama dimulai dengan pengenalan tim pengabdian yang disertakan penjelasan metode pelaksanaan kepada pihak peserta dan mitra. Dilakukan penjelasan tentang evaluasi kinerja PLTS yang yang telah ada serta kebutuhan daya untuk dapat mengembangkan PLTS apabila terdapat penambahan fasilitas pompa air submersible. Aktivitas yang dilakukan pada pertemuan kedua, pelaksanaan kegiatan berupa Pengenalan re-design dan perhitungan daya PLTS untuk pompa submersible. Proses yang dilakukan pertemuan kedua berupa presentasi dari tim pengabdian dilanjutkan dengan tanya-jawab tentang re-design dan perhitungan daya PLTS sehingga peserta mengetahui rencana pengembangan lingkungan greenhouse hidroganik dengan penambahan kapasitas PLTS. Gambar 4 menyajikan re-design pompa submersible energi surya.
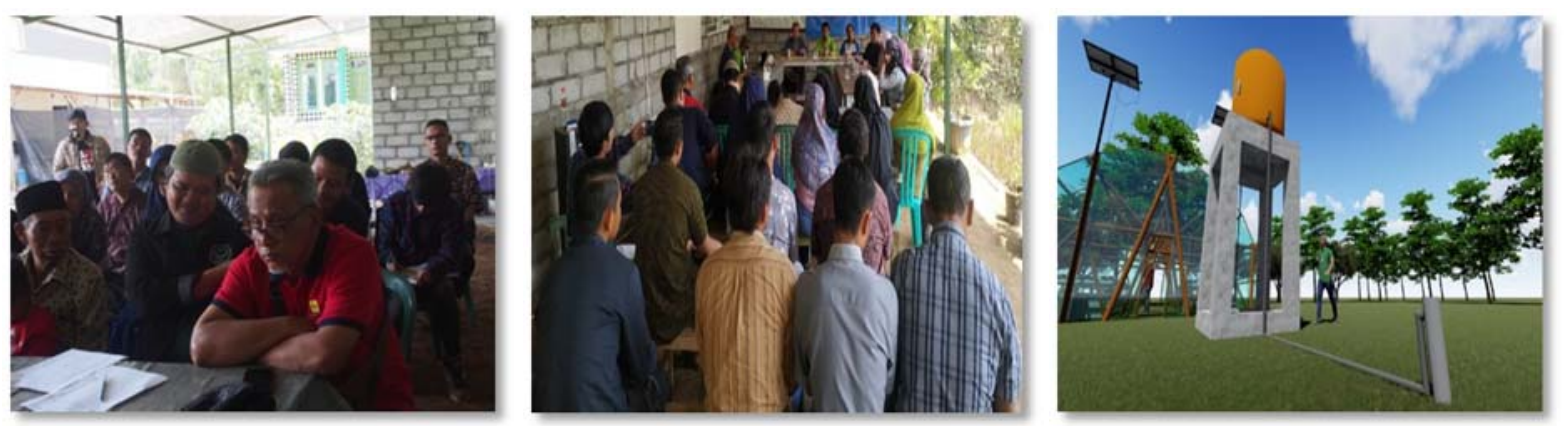

Gambar 3. Aktivitas penjelasan program pengembangan PLTS

Gambar 4. Re-design pompa submersible energi surya

Pertemuan ketiga, Penjelasan komponen PLTS untuk pompa submersible dan fungsi masingmasing. Pada pertemuan ketiga ini peserta diajak untuk berpartisipasi dalam mengenal komponenkomponen PLTS beserta spesifikasinya. Gambar 5 menunjukkan proses pengenalan komponen panel surya. Selain pengenalan komponen PLTS, pada pertemuan kali ini juga dapat disaksikan proses pengelasan dan perakitan bracket (alat penopang) panel surya.
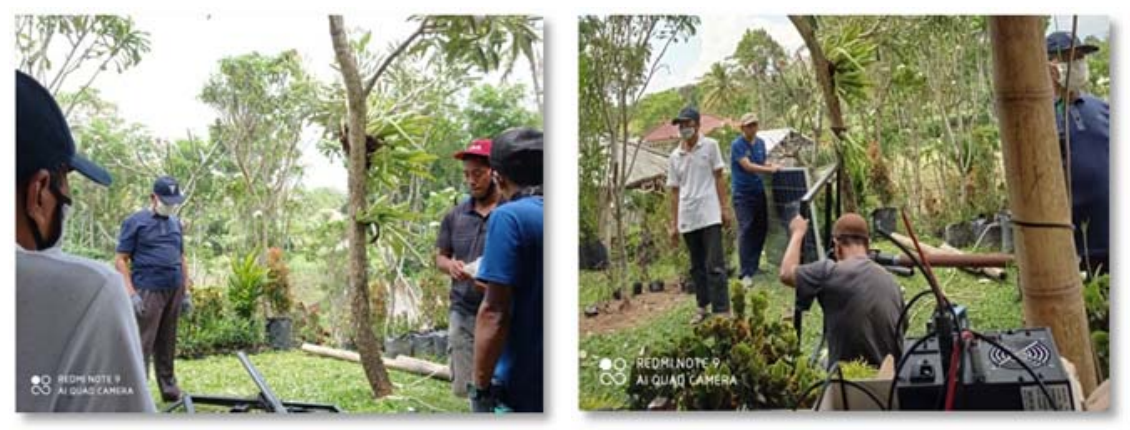

Gambar 5. Pengenalan komponen panel surya

Pertemuan keempat, berupa pengenalan dan pemasangan bracket-panel surya yang telah dirakit untuk ditempatkan pada salah satu sisi greenhouse hidroganik. Pada pertemuan ketiga ini peserta diajak untuk berpartisipasi dalam pemasangan bracket-panel surya PLTS pada tempat yang telah disiapkan. 

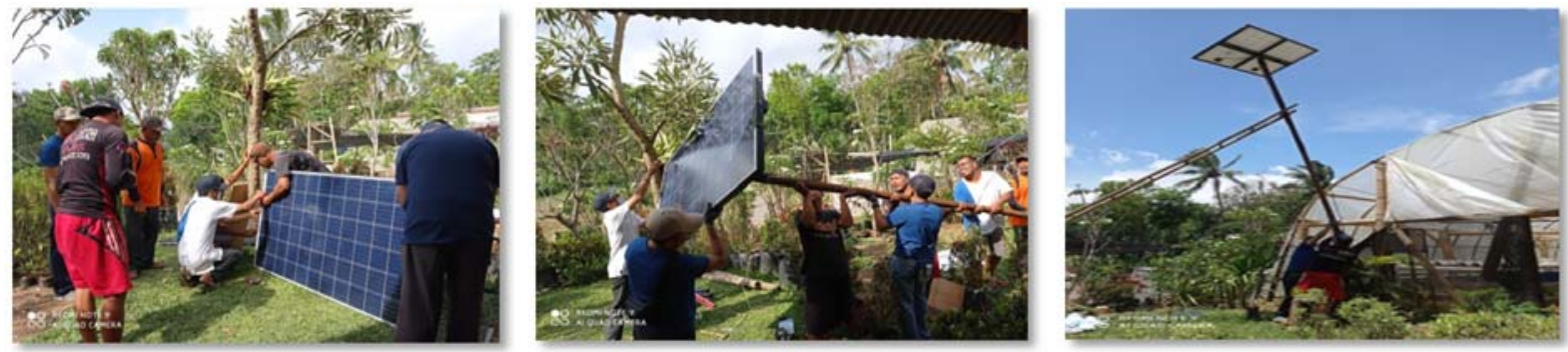

Gambar 6. Aktivitas pemasangan bracket-panel surya

Pertemuan hari kelima, berupa pengenalan dan pemasangan power bank, yaitu pusat kontrol dan penyimpanan daya PLTS, terdiri dari charge controller, battery, dan inverter. Dengan dipasangnya power bank ini maka perangkat PLTS yang mensuplai listrik untuk pompa submersible, pompa sirkulasi hidroganik dan lampu penerangan greenhouse sudah siap untuk dioperasionalkan.
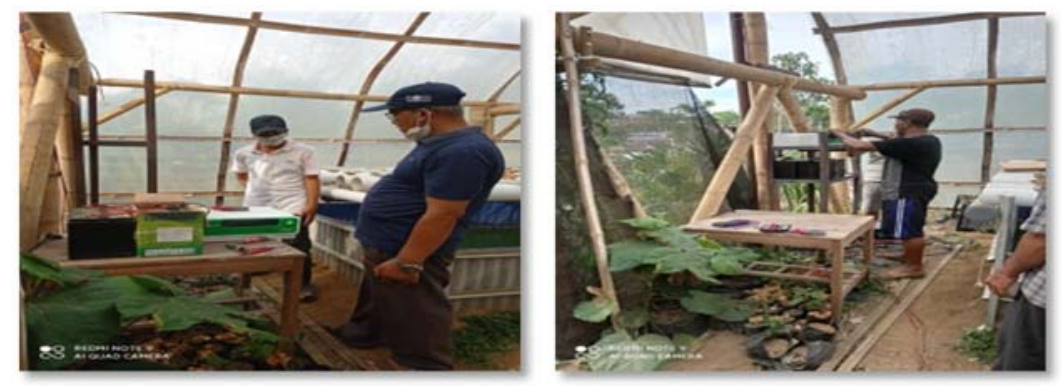

Gambar 7. Pemasangan power bank pada PLTS

Pada pertemuan keenam, pelaksanaan kegiatan evaluasi terhadap kinerja seluruh komponen PLTS dan pompa submersible serta pompa sirkulasi air greenhouse. Aktivitas yang dilakukan pengukuran kekuatan cahaya matahari, voltase dan daya oleh panel surya serta debit air yang dihasilkan oleh pompa submersible. Berdasarkan pengukuran, maka PLTS telah mampu untuk mensuplai listrik untuk pompa submersible, pompa sirkulasi hidroganik dan lampu penerangan greenhouse. Gambar 8 menunjukkan kolam pemnampungan air yang dapat dialiri oleh pompa submersible sebanyak 4.572 liter hanya dalam waktu 2 jam sehingga sangat cukup untuk kebutuhan tanaman pada greenhouse hidroganik, bahkan dapat digunakan untuk tanaman di sekitarnya.
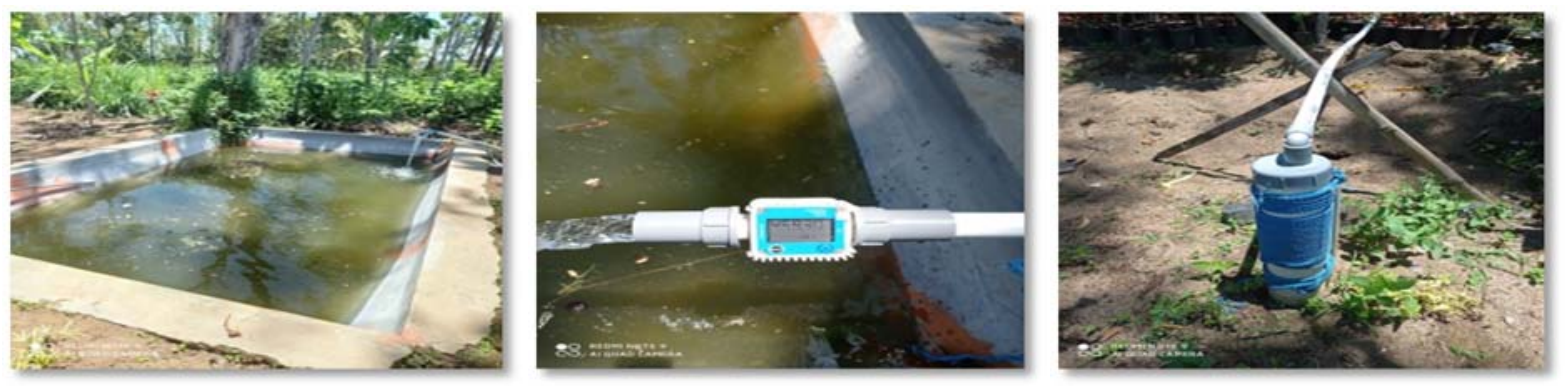

Gambar 8. Bak air, alat ukur debit air, dan pompa submersible 
ABDIMAS: Jurnal Pengabdian Masyarakat Universitas Merdeka Malang

Volume 6, No. 3, August 2021: 336-346

Hari ketujuh, aktivitas yang dilakukan adalah ucapan terima kasih dan kata penutup oleh tim pelaksana program pengabdian Univesitas Medeka Malang yang dilanjutkan denganpenutup dan ucapan terima kasih dari pihak POKDARWIS.

\section{Pembahasan}

Penataan kembali PLTS untuk pompa submersible dengan aktivitas berupa sosialisasi, pengenalan PLTS dan komponennya, dan pemasangan bersama ini relevan dengan program nasional pemanfaatan energi surya untuk pertanian secara modern umumnya dan khususnya untuk lingkungan greenhouse hidroganik Grangsil.

Hasil diskusi antara tim pengabdian dan peserta kegiatan, menunjukkan bahwa kegiatan program pengabdian kepada masyarakat oleh tim pelaksana dari Universitas Merdeka Malang memberikan hasil sebagai berikut: (1) Kegiatan tim pengabdian pada masyarakat ini telah meningkatkan dan menambah pemahaman anggota POKDARWIS Desa Jambangan Kecamatan Dampit Kabupaten Malang dalam praktik penataan kembali PLTS untuk greenhouse hidroganik. Peningkatan pemahaman ini dapat dilihat dari adanya kemampuan untuk mengoperasikan PLTS greenhouse hidroganik. Selain itu, pemahaman peserta dapat dilihat dari keaktifan peserta dalam mengikuti program secara kontinyu dari awal sampai akhir; (2) Meningkatnya pengetahuan peserta mengenai pengopersian PLTS greenhouse hidroganik serta adanya pengetahuan tambahan mengenai cara monitoring dan pemeliharannya.

Terdapat beberapa faktor penghambat dalam pelaksanaan program pengabdian pada masyarakat ini, antara lain: (1) Peserta pelatihan merupakan masyarakat awam maka kebanyakan peserta yang baru mengetahui adanya teknik pengelolaan PLTS; (2) Sebagian peserta merasa takut listrik pada saat melakukan Praktik, disebabkan pada awal pertemuan, belum faham tentang karakteristik arus listrik pada PLTS.

\section{SIMPULAN DAN SARAN}

Untuk memenuhi kebutuhan air pertanian maka dapat dilakukan pencarian sumber air melalui pengeboran tanah. Apabila sumber air tanah berada pada kedalaman lebih dari 20 meter akan lebih efektif menggunakan pompa jenis submersible. Sebuah pompa submersible 450 Watt yang bekerja 2 jam per hari dan 2 (dua) buah pompa sirkulasi air hidroganik masing-masing 35 Watt yang bekerja 12 jam per hari, memerlukan 2 (dua) buah panel surya 250 Wp, 3 (tiga) buah battery 100 Ah 12 Volt dan 1 (satu) buah inverter 1.500 Watt. Pompa submersible 450 Watt yang bekerja 2 jam per hari dapat menghasilkan air sejumlah 4.572 liter/hari yang sangat mencukupi untuk kebutuhan pertanian sayur dengan sistem hidroganik di dalam greenhouse.

Prototipe pompa submersible tenaga surya untuk lingkungan pertanian ini dapat dijadikan pedoman bagi perorangan, lembaga swasta maupun Pemerintah untuk dikembangkan di daerah lain secara nasional. Kelebihan volume air yang dihasilkan oleh prototipe ini dapat disalurkan untuk pengembangan pertanian di sekitar greenhouse hidroganik, misalnya pertanian sayur organic dengan polybag, kebutuhan air MCK bagi penjaga kebun pertanian, dan kebutuhan lainnya. 
Listrik Tenaga Surya untuk Pompa Submersible pada Greenhouse Hidroganik di Kabupaten Malang

Hery Budiyanto, Pindo Tutuko, Aries Boedi Setiawan, Razqyan Mas Bimatyugra Jati, Muhammad lqbal

\section{UCAPAN TERIMA KASIH}

Ucapan terima kasih kami haturkan kepada Universitas Merdeka Malang yang telah mendanai program ini, demikian pula kepada jajaran LPPM yang telah mendukung pelaksanaan program ini.

\section{DAFTAR PUSTAKA}

Apribowo, C. H. B., \& Anwar, M. (2017). Prototype sistem pompa air tenaga surya untuk meningkatkan produktivitas hasil pertanian. Jurnal Abdimas, 21(2), 97-102.

Budiyanto, H., Haris, M., \& Setiawan, A. B. (2019). The bamboo greenhouse technology for hydroganic crops with independent photovoltaic electricity. International Journal of Science and Engineering Applications, 8(12), 517-521. https://doi.org/10.7753/IJSEA0812.1004

Ekawita, R., Supiyati, S., \& Yuliza, E. (2020). Peningkatan skill dan pengetahuan masyarakat tentang instalasi panel surya sebagai sumber energi listrik alternatif. PengabdianMu: Jurnal Ilmiah Pengabdian Kepada Masyarakat, 6(1), 44-47.

Hartono, B., \& Purwanto, P. (2015). Perancangan pompa air tenaga surya guna memindahkan air bersih ke tangki penampung. SINTEK: Jurnal Mesin Teknologi, 9(1), 28-33.

Muttaqin, I., Irhamni, G., \& Agani, W. (2016). Analisa rancangan sel surya dengan kapasitas 50 watt untuk penerangan parkiran Uniska. Al-Jazari: Jurnal Ilmiah Teknik Mesin, 1(1), 33-39.

http://dx.doi.org/10.31602/al-jazari.v1i1.465

Indrizal, E. (2014). Diskusi kelompok terarah focus group discussion (FGD): Prinsip-prinsip dan langkah pelaksanaan lapangan. Jurnal Antropologi (Jantro): Isu-Isu Sosial Budaya, 16(1), 75-82. https://doi.org/10.25077/jantro.v16.n1.p75-82.2014

Iqtimal, Z., Sara, I. D., \& Syahrizal, S. (2018). Aplikasi sistem tenaga surya sebagai sumber tenaga listrik pompa air. Jurnal Karya Ilmiah Teknik Elektro, 3(1), 1-8.

Kalyani, V. L., Dudy, M. K., \& Pareek, S. (2015). Green energy: The need of the world. International Journal of Computer Science and Information Security, 2(5), 18-26.

Pratama, D. A., \& Siregar, I. H. (2018). Uji kinerja panel surya tipe Polycrystallin 100WP. Jurnal Pendidikan Teknik Mesin, 6(03), 79-85.

Purwanto, I. (2020). Solar cell (Photovoltaic/PV) solusi menuju pulau mandiri listrik. Jurnal Penelitian dan Karya Ilmiah Lembaga Penelitian Universitas Trisakti, 5(2), 117-126.

http://dx.doi.org/10.25105/pdk.v5i2.7410

Rif'an, M., Pramono, S. H., Shidiq, M., Yuwono, R., Suyono, H., \& Suhartati, F. (2012). Optimasi pemanfaatan energi listrik tenaga matahari di Jurusan Teknik Elektro Universitas Brawijaya. Jurnal EECCIS, 6(1), 44-48.

Rosalina, R., \& Sinduningrum, E. (2019). Penerapan pembangkit listrik tenaga surya di lahan pertanian terpadu Ciseeng Parung Bogor. Prosiding Seminar Nasional Teknoka ke-4, 4, E74-E83. https://doi.org/10.22236/teknoka.v4i0.4188

Sanjaya, O. I., Giriantari, I. A. D., \& Kumara, I. N. S. (2019). Perancangan sistem pompa irigasi pembangkit listrik tenaga surya (PTLS) untuk pertanian Subak Semaagung. Jurnal SPEKTRUM, 6(3), 114121. https://doi.org/10.24843/SPEKTRUM.2019.v06.i03.p16 
ABDIMAS: Jurnal Pengabdian Masyarakat Universitas Merdeka Malang Volume 6, No. 3, August 2021: 336-346

Santoso, H. B., Saodah, S., Utami, S., \& Baisrum, B. (2020). Sosialisasi dan implementasi renewable energy di SMKN 1 Cimahi. Jurnal Difusi, 3(1), 44-52. https://doi.org/10.35313/difusi.v3i1.1948

Setiawan, B., Hidayat, G., \& Candra, A. Y. (2017). Rancang bangun DC submersible pump sistem photovoltaic battery coupled dengan panel surya tipe polycrystalline skala laboratorium. Seminar Nasional Sains dan Teknologi, (TM-019), 1-8.

Sofyar, H. (2017). Teknik konservasi energi pada pompa submersible dengan menggunakan variable frequency drive. ELTIKOM: Jurnal Teknik Elektro, Teknologi Informasi dan Komputer, 1(2), 84-93. https://doi.org/10.31961/eltikom.v1i2.25

Sontake, V. C., \& Kalamkar, V. R. (2016). Solar photovoltaic water pumping system: A comprehensive review. Renewable and Sustainable Energy Reviews, 59, 1038-1067.

https://doi.org/10.1016/j.rser.2016.01.021

Suryani, A., Fadhillah, A. P., Saichu, S., \& Mubarok, H. (2018). Instalasi Pembangkit Listrik Tenaga Surya Dos \& Don'ts. (B. Ramadhani, Ed.) (1st ed.). Jakarta: Deutsche Gesellschaft für Internationale Zusammenarbeit (GIZ) GmbH.

Zainuddin, D., Wiratmani, E., \& Usman, R. (2019). Pengabdian kepada masyarakat anggota pemberdayaan kesejahteraan keluarga di Kelurahan Cinere dan Kelurahan Gandul Depok Jawa Barat. Abdimas Universal, 1(2), 1-4. https://doi.org/10.36277/abdimasuniversal.v1i2.28 